\title{
車両前面衝突時の乗員胸部傷害值を低減する 腰部拘束装置の開発*
}

\author{
田岡義文*1 \\ Development of Pelvis Anti Submarine Device \\ to Reduce Chest Injury for Frontal Impact of Vehicle
}

\author{
Yoshifumi TAOKA*2 \\ ${ }^{* 2}$ Daihatsu Motor Co., Ltd. Vehicle Research \& Development Div, \\ 2-1-1 Momozono, Ikeda-shi, Osaka, 563-8651 Japan
}

\begin{abstract}
It is a very important subject to reduce chest deceleration when frontal crash impact of vehicle occurs. One of the most efficient methods of reducing chest deceleration is to optimize pelvis deceleration of vertical direction. The purpose of this development is to design a new concept of anti submarine device, which is more efficient, economical, and no partial injury of human body. This developmental new device can lift up the anti submarine pipe toward pelvis direction by utilizing inertial force, which occurs in frontal crash impact of vehicle instead of using pyrotechnical explosion power that acts by the signal of electronic crash sensor. Through this investigation, we also obtained that it became possible to reduce chest maximum deceleration of horizontal direction by increasing pelvis deceleration of vertical direction in the first period of vehicle crash and by decreasing pelvis deceleration of vertical direction in the middle and the latter period of vehicle crash.
\end{abstract}

Key Words : Automobile, Safety Engineering, Bio-Motion, Dynamics of Machinery, Motion Control

\section{1. 緒論}

近年の自動車開発において, 車両前面衝突時の乗員 挙動や乗員傷害値の計算に関しては MADYMOなど の CAE解析ソフトが存在しており,これらを用いた 解析 ${ }^{(1)}$ や, 多質点系バネマスモデルを用いた解析(2) (4) が多く行われている。一方で前面衝突を模擬したスレ ッド試験による傷害值の解析も広く実施されている が, これまでの弊社での試験結果解析により, 重要な 乗員傷害値の一つである胸部減速度は, 腰の上下方向 減速度の変化に大きな影響を受けていると著者は考え ている.しかし現状においてここに的を絞った理論, 実験解析や，それに基づく商品の開発はさほどなされ ていない.

本研究では腰の拘束方法として, 現在一部車両で市 販されている衝突時の減速度の電気信号をセンサで感 知した後, 火薬類で腰拘束装置を作動させるような方 法(5)をとらず, 車両衝突時の車体減速度によりシート に発生する慣性力を有効に利用して, 衝突後の時間ご との腰上下減速度をコントロールし, 胸部傷害值低減

* 原稿受付 2005 年 5 月 2 日.

*1 正員, ダイハツ工業(株) ( 563-8651 池田市桃園 2-1-1).

E-mail : Yoshifumi_Taoka@mail.daihatsu.co.jp
に効果があり，かつ乗員の局部的部位への攻撃性も少 ない腰拘束装置を開発した，本装置を用いた前面衝突 模擬スレッド試験により, 胸部減速度の最大值を下げ るためには腰上下減速度をいかに変化させればよいの かについての知見も導出したので紹介する.

\section{2. 現 状 分 析}

図 1 に実際の衝突試験で用いられている計測用ダミ ー (Hybrid III) を示す. 腰部と胸部の連結は人体の腰 椎を擬似しており, 内部にワイヤの入った硬質ゴムで 構成されたランバースパインと称する部品で連結され ている．したがって腰から前後方向, 上下方向の減速 度が加わった場合, ランバースパインに曲げモーメン トが伝ぱし, 胸部の減速度に影響を与える。

この影響を確認するために, 図 2 に示すように Hybrid IIIダミーをシートに着座させて, シートベル トでダミーを拘束させた状態での前面衝突模擬スレッ ド試験を 3 ショット行った。 シートおよびシートベル トは表 1 のような仕様とし, 外乱要素を取り除くため, ステアリングおよびステアリング内蔵エアバッグは取 り外した状態としている.試験結果を図 3 に示す.グ ラフは横軸を時間とした場合の, 上から胸部合成減速 度, 胸部前後 $(X)$ 方向減速度, 腰部上下 $(Z)$ 方向減速 
度，腰部前後 $(X)$ 方向減速度を示す，時間歴で見る

と，特に前突時に問題となる 0 ～ $80 \mathrm{~ms}$ 間においては， 胸部合成減速度に支配的な前後方向の胸部減速度は腰 部前後 $(X)$ 方向減速度よりも腰部上下 $(Z)$ 方向減速 度にグラフの形状が擬似 (山部が対応)しており, 影響 度合いが大きいといえる。特にType 3 においては, $42 \mathrm{~ms}$ 付近にてダブルプリテンの影響により腰がシー トのボトムパネルに押付けられ, 高い腰上下減速度が 胸の減速度に伝わったことがグラフより読み取れる。 なお本スレッド試験時, 入力值として用いた車体側減 速度波形を図 4 に示す。

Table 1 Parameters of seat and seat belt structure

\begin{tabular}{|c|c|c|}
\hline & $\begin{array}{c}\text { Structure of } \\
\text { Seat CushionFrame }\end{array}$ & $\begin{array}{c}\text { Structure of } \\
\text { Seat Belt }\end{array}$ \\
\hline Type 1 & $\begin{array}{c}\text { WithSShaped } \\
\text { Spring Suspension }\end{array}$ & WithEL R Pretensioner \\
\hline Type 2 & Bottom Panel & $\uparrow$ \\
\hline Type3 & $\uparrow$ & $\begin{array}{c}\text { WithEI R and Lap Outer } \\
\text { Pretensioner }\end{array}$ \\
\hline
\end{tabular}

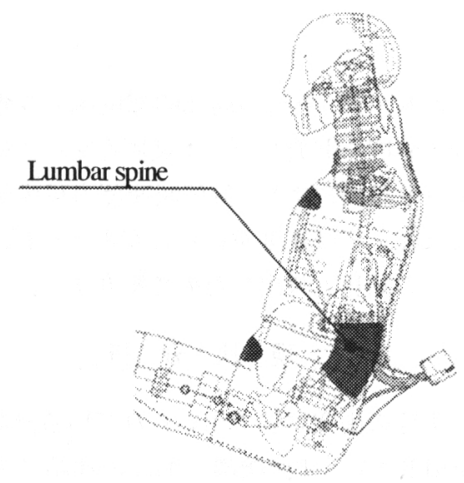

Fig. 1 Structure of Hybrid III Dummy

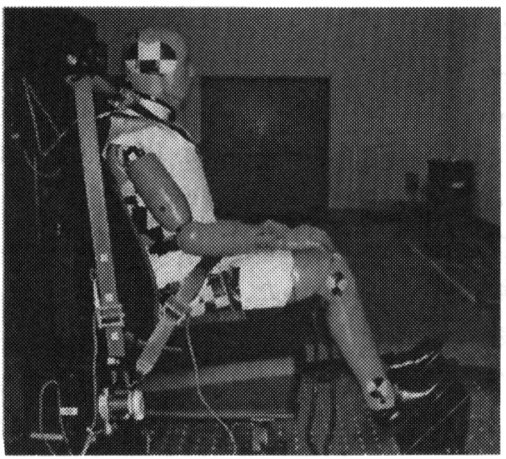

Fig. 2 Sled test apparatus of seat, seatbelt, and Hybrid III dummy

\section{3. 新規腰拘束装置の開発}

$3 \cdot 1$ 開発の狙い 2 章での試験結果により, 胸減 速度の最大值を下げるためには, 衝突初期に腰上下減 速度を高めてやることにより胸の初期拘束性能を向上 させて, 衝突エネルギーの吸収を効率良く行い, 衝突 中期〜後期においては腰への入力を低下させることに

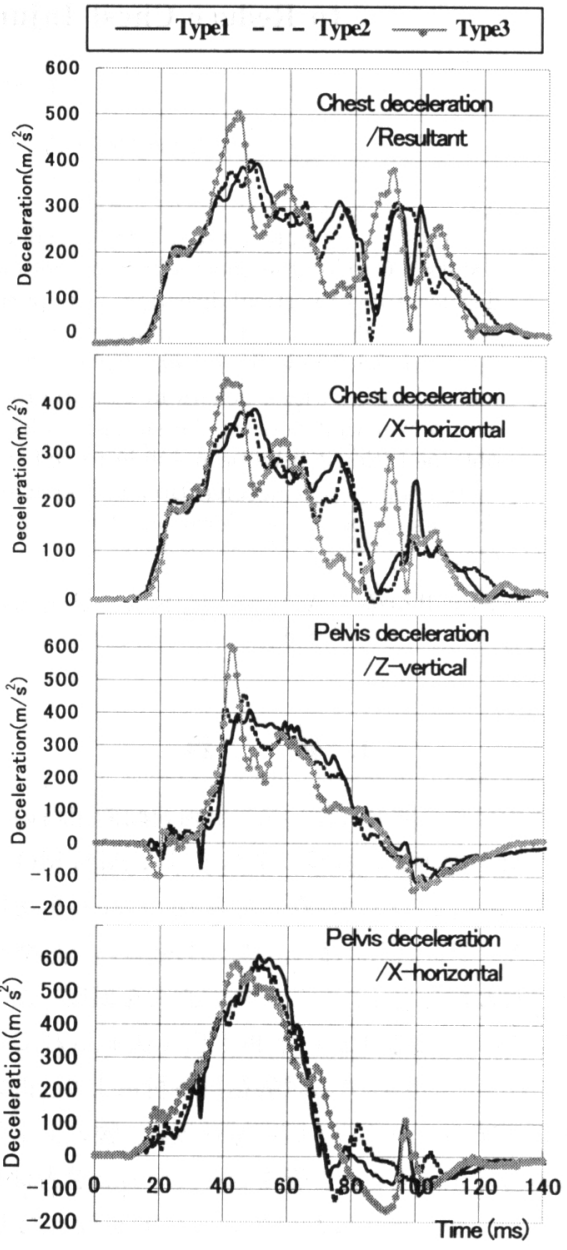

Fig. 3 Result of occupant deceleration curve

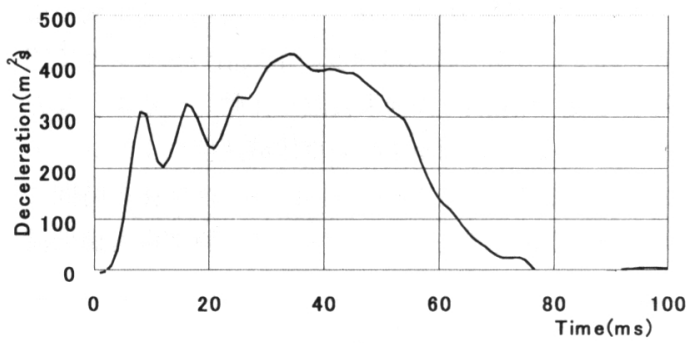

Fig. 4 Vehicle deceleration curve 
より, 胸への減速度上乗せを排除してやればよいと考 えられる.腰への上下減速度入力を得るためには, シ 一ト着座時大腿部の下方に前突時の尻部を受ける部材 を設定する方法があるが, 通常着座状態で異物感が発 生し, 商品性も低下してしまう。これを防止するため に現在製品化されている商品としては, 通常状態では 大腿部や尻部に対し異物感のない位置にまで部材を下 げて設定しておき, 衝突時のみ検知した衝突信号から インフレータを着火させ, 部材を上方に持ち上げる機 構があるが, 原価面で高価なことや, インフレータに より高速度で動く部材が人体へ与える影響に眯念があ る。これらを防止するため, 通常着座状態では大腿部 より遠い位置にある部材を，インフレータを用いず， 車両前突時車体に加わる慣性力を利用して持ち上げる $\operatorname{ASD}$ (Anti Submarine Device) 機構を考案した。また この部材は衝突中期〜後期には変形させるか, または 下方に落とし込むことにより, 腰から胸への過度な荷 重伝ぱを阻止することを狙った。

$3 \cdot 2 \mathrm{ASD}$ 開発品の設計仕様 考案したASDの シートへの組込み状態図, 部品構成図, 作動原理図を それぞれ図 5〜 7 に示す. 図 5～7 のように, 車両前突 時は車体に発生した慣性力により, 装置に設定された

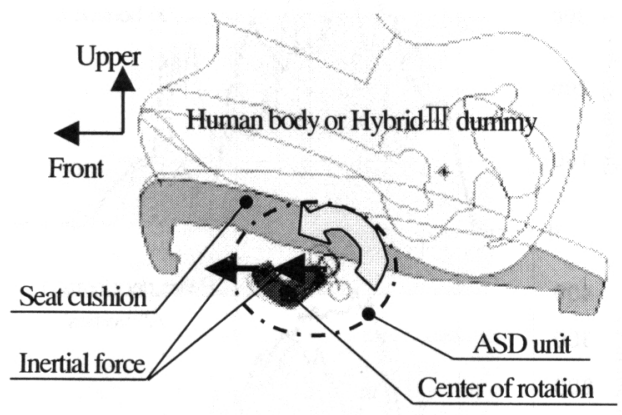

Fig. 5 Principle of ASD acting system



Fig. 6 Dissolved view of ASD
慣性マスとパイプが回転中心にて反時計回りに回転す ることによりパイプが乗員側に持ち上がる。また車体 の慣性力が減少するとパイプは衝突前の初期位置の方 向に時計回りに回転するＡSDの設計に当たっては， 図 4 に示す車体側減速度が加わったときに確実に ASD が作動するようスペックを定めていった.ここ で図 8 に基づき，記号を下記のように定義する。

$m_{1}: \mathrm{ASD}$ パイプ側質量 (アームの一部も含む) $m_{2}$ : ASD 慣性マス側質量(アームの一部も含む)

$F_{0}$ : Hybrid III ダミーから $m_{1}$ 重心に下方向に加 わる力 (シートに Hybrid IIIダミーを着座さ せ, パイプ挿入位置直上のダミー左右大腿部 を負荷して, 大腿部が左右とも持ち上がる最 小荷重を測定)

$F_{1}: m_{1}$ 重心に下方向に加わる力の合計

$F_{2}: m_{1}$ 重心に前方向に加わる力

$F_{3}: m_{1}$ 重心に回転方向に加わる力

$f_{1}: m_{2}$ 重心に下方向に加わる力

$f_{2}: m_{2}$ 重心に前方向に加わる力

$g$ : 重力加速度



Fig. 7 Side view of ASD

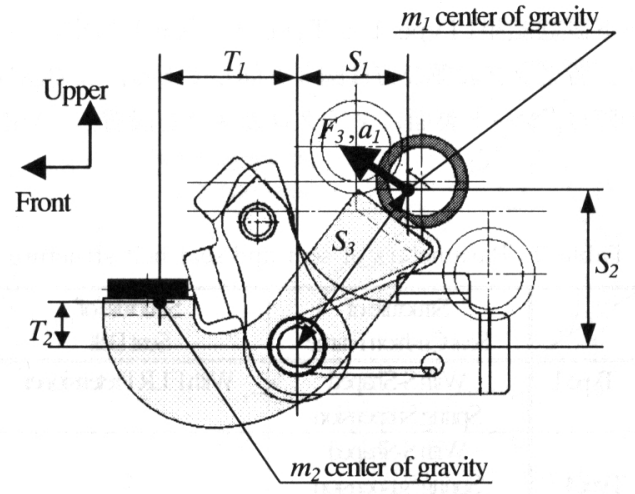

Fig. 8 Definition of physical elements 
$a_{0}:$ 車体側減速度

$a_{1}: m_{1}$ 重心に回転方向に加わる減速度

$K$ : トーションスプリングの復元モーメント

$S_{1}: \mathrm{ASD}$ 回転中心から $m_{1}$ 重心までの前後寸法

$S_{2}: \mathrm{ASD}$ 回転中心から $m_{1}$ 重心までの上下寸法

$S_{3}: \mathrm{ASD}$ 回転中心から $m_{1}$ 重心までの実寸法

$T_{1}: \mathrm{ASD}$ 回転中心から $m_{2}$ 重心までの前後寸法

$T_{2}:$ ASD 回転中心から $m_{2}$ 重心までの上下寸法 衝突時に発生する力は,

$F_{1}=m_{1} g+F_{0} \cdots$

$F_{2}=m_{1} a_{0}$

$f_{1}=m_{2} g$

$f_{2}=m_{2} a_{0}$

反時計回りに発生するモーメントを $M$ とすると

$M=F_{2} S_{2}+f_{2} T_{2}+f_{1} T_{1}+K-F_{1} S_{1}$

$=F_{3} S_{3}=m_{1} a_{1} S_{3}$

$\therefore \quad a_{1}=M / m_{1} S_{3}$

一方，ASDのパイプが通常着座位置より最上段に持 ち上がった位置に達するまでの時間を $t_{1}$ ，そのときの $m_{1}$ 重心における回転方向の移動距離を $L_{1}$ とすると

$a_{1}=2 L_{1} / t_{1}^{2}$

作動に必要な $L_{1}$ 值, $t_{1}$ 值はシートとしての乗り心地 性能要件と 2 章によるスレッド試験結果より目標値を 定めることができるため，これらの条件を基にして $a_{1}$ を求めた後, $a_{1}$ を満足するための各部品形状と寸法, 質量, トーションスプリング仕様などを定めていっ た.

\section{ASD 組込み試験結果と考察}

4・1 ASD 組込みスレッド試験結果３章の設計 計算に基づき ASD を試作し，2 章でのスレッド試験 と同条件で新たにスレッド試験を行った。ASD は Type 1 のシートに組込み, シートベルト仕様も Type 1 に合わせ,これを Type 4 とした(表 2 参照). スレ ッド試験結果(Type 1 と Type 4 の比較)を図 9 に示 す. 各グラフの並び方は図 3 と同じである。なお試験 の際は, シート裏面にマイクロカメラを設置し, ASD

Table 2 Parameters of seat and seat belt structure

\begin{tabular}{|c|c|c|}
\hline & $\begin{array}{c}\text { Structure of } \\
\text { Seat CushionFrame }\end{array}$ & $\begin{array}{c}\text { Structure of } \\
\text { SeatBell }\end{array}$ \\
\hline Type1 & $\begin{array}{c}\text { WithSShaped } \\
\text { SpringSuspension }\end{array}$ & WithEIRPretensioner \\
\hline Typo4 & $\begin{array}{c}\text { WihSShaped } \\
\text { SpringSuspension } \\
\text { Plus ASD }\end{array}$ & $\uparrow$ \\
\hline
\end{tabular}

挙動をコマ取り撮影することにより, ASD が狙い通 りに作動しているかどうか確認した(図 10 参照).

コマ撮り撮影の結果, ASDのパイプは車体減速度 の増加に伴って発生する慣性力により, ダミーがパイ プを押付ける力 $F_{0}$ に打勝って上昇を開始し, $32 \mathrm{~ms}$ 付近にてパイプが最上端位置に達し，しばらくこの状 態を維持するが，車体減速度の隇少とともにパイプは 落ち込み始め, $86 \mathrm{~ms}$ 付近ではほぼ初期位置まで戻 る.この間でパイプ自体も変形し, 衝突エネルギーを 吸収する。このような ASD の挙動結果は図 9 のグラ フにもよく反映されており, $30 \mathrm{~ms}$ 付近での腰上下減 速度上昇による胸前後隇速度上昇に結びついている.

$$
\text { - - Type1 Type4 }
$$
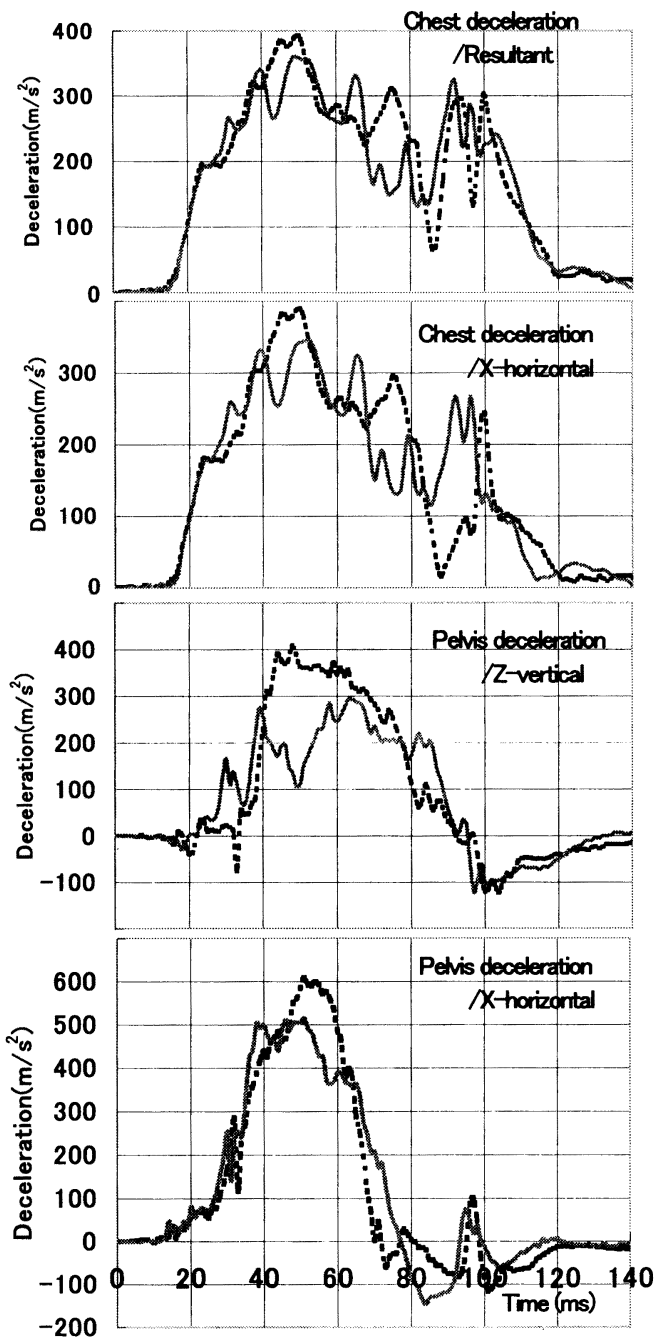

Fig. 9 Result of occupant deceleration curve 
また 40〜 60 ms ではパイプの変形とパイプの下降開 始により腰上下減速度が低下し, 胸前後減速度のピー ク值低減に貢献している。図 11 に試験後のシートク ッションフレーム状態を示す。試験前にはストレート だったパイプが試験後にはエネルギーを吸収してわん 曲していることがわかる.

$4 \cdot 2$ 衝突エネルギー消費の面から見た考察 本 スレッド試験結果をエネルギーの観点でグラフ化した ものを図 12 に示す。このグラフは縦軸に胸部前後減 速度, 横軸に地上基準で見た胸部移動量を示す。グラ フで囲まれた面積は胸部の運動エネルギーを胸部質量 で割り算したものになり, 同一の車体減速度を与えた 場合は Type 1 も Type 4 も同じ值となる.したがっ
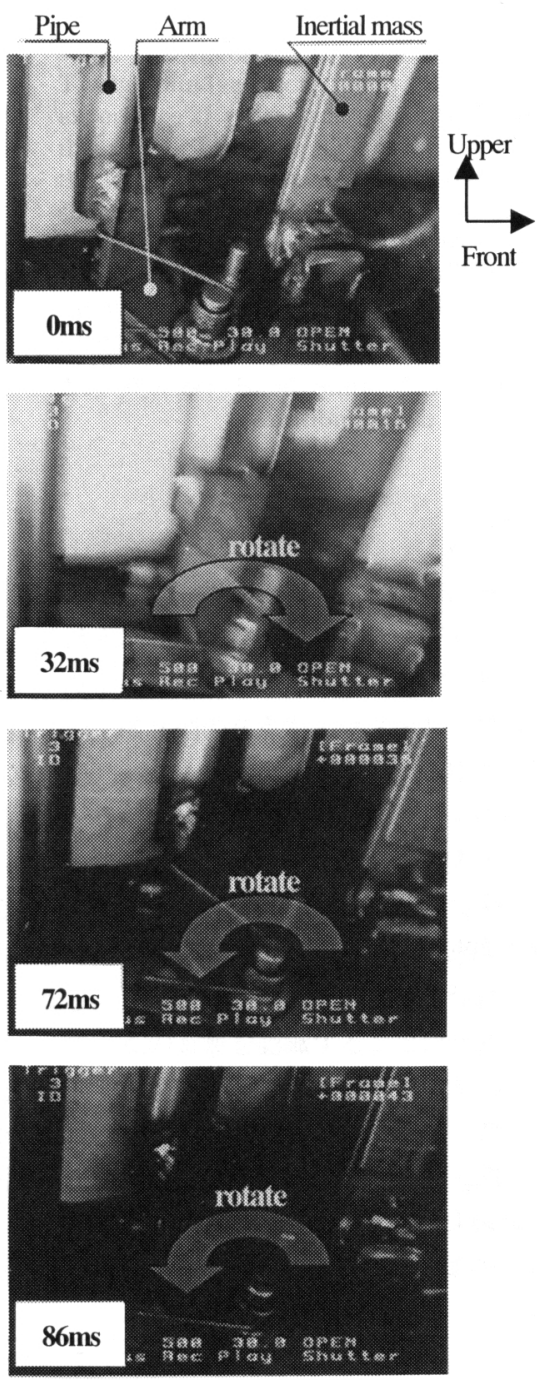

Fig. 10 Motion of ASD by sled test
て胸の許容移動量を同一としたときは, 初期のグラフ の傾きを大きくし, 初期エネルギーを高くしてグラフ で井まれた面積を大きくすることによりエネルギーの 消費を多くし, 衝突中期〜後期のピーク減速度が下が りやすくなるようコントロールしていくことが望まし い. その点今回設計, 評価した ASD は, 通常のシー 卜 (Type 1) に対し, 胸部合成減速度の最大值で比較す ると $32 \mathrm{~m} / \mathrm{s}^{2}$ の低減効果が得られており, 図 12 の工 ネルギー特性比較でも狙いに合ったグラフ形状が得ら れたため, 本 ASD は $3 ・ 1$ 節の狙いにうまく適合した 乗員拘束システムになっていると考光る.

\section{5. 結言}

車両前面衝突時乗員が受ける重大な傷害値の一つで ある胸部減速度を下げるために, 腰の上下減速度に着 目し，衝突時の車体減速による慣性力を有効活用した 乗員拘束システムを設計, 試作評価し, 効果を得るこ とができた。これによれば, 衝突初期段階(図 4 に示 す車体減速度条件では $0 \sim 39 \mathrm{~ms}$ 付近)では, 極力腰へ の上方向荷重を与えることにより，胸部への初期減速 度立上りを増加させて衝突エネルギーを消化させ, 衝 突中期〜後期段階(図 4 に示す車体減速度条件では 40

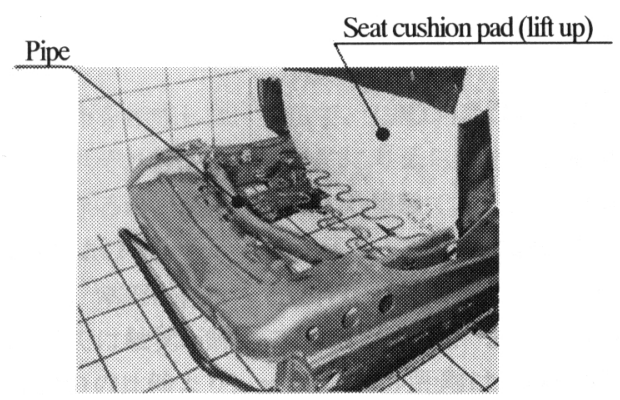

Fig. 11 Seat cushion frame with ASD (after the sled test)

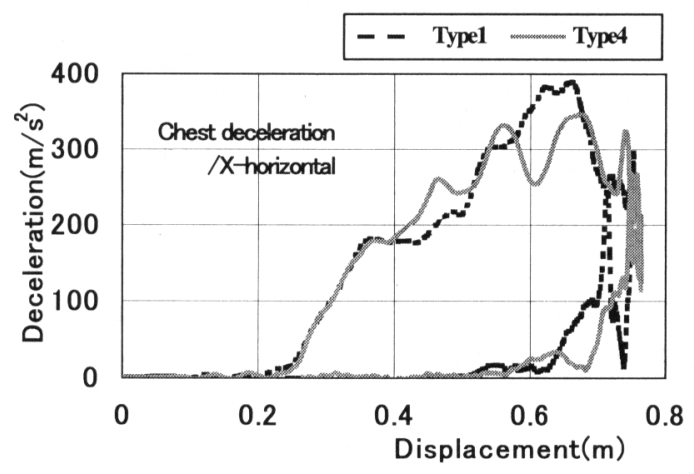

Fig. 12 Result of occupant deceleration curve 
$\mathrm{ms}$ 以降)では, 極力腰への上方向荷重を弱めてやり, 胸部に伝わる減速度を下げることが胸部のピーク減速 度を下げることに貢献することが確認できた．本シス テムは商品化に向けて開発を続行中である.

終わりに, 本研究開発において部品製作や実験に協 力していただいた富士シート(株)のご担当者の方々に 感謝の意を表す。

\section{文献}

（1）伊藤秀樹・橋本大一・清水信行, MADYMOに上る衝突
時の乗員挙動解析(エアバッグの適用に関するフィジビ リティ・スタディ), 機論, 57-539, C(1991), 2205-2210.

（2）近藤正直 - 高橋邦弘, 衝突時の車体減速度波形と乗員隇 速度, 自動車技術会論文集, No. 35 （1987），154-161。

（3）大村英夫, 正面衝突時における乗員挙動解析について, 自 動車技術, 42-10（1988），1336-1342, 自動車技術会.

（4）鈴木直幸・園田義晴・高橋邦弘・鈴木健弘・俵山崇・独 古泰裕, 車体減速度波形の乗員傷害值に対する最適化, 自 動車技術会論文集, 24-4（1993），109-112.

（5）速水則行, MADYMOによるシート性能評価一CRD (Cushion Restraint Device) シートの効果検討, (2000), 豊田中央研究所・業務報告書, 200001103. 